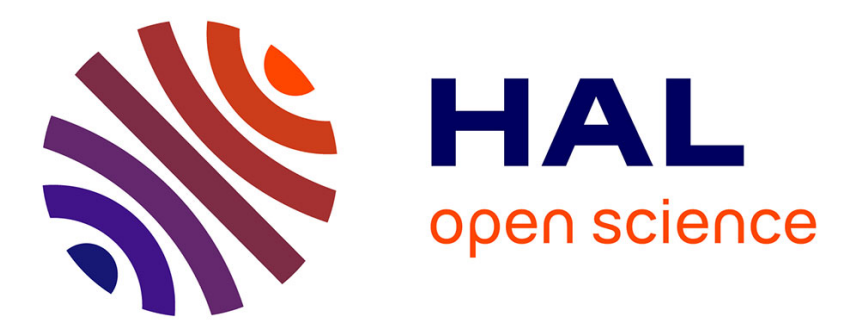

\title{
Ionic Schiff base dioxidomolybdenum(VI) complexes as catalysts in ionic liquid media for cyclooctene epoxidation
}

Rinaldo Poli, Christine Bibal, Jean-Claude Daran, Simon Deroover

\section{- To cite this version:}

Rinaldo Poli, Christine Bibal, Jean-Claude Daran, Simon Deroover. Ionic Schiff base dioxidomolybdenum(VI) complexes as catalysts in ionic liquid media for cyclooctene epoxidation. Polyhedron, 2010, 29 (1), pp.639-647. 10.1016/j.poly.2009.09.001 . hal-03178288

\section{HAL Id: hal-03178288 \\ https://hal.science/hal-03178288}

Submitted on 23 Mar 2021

HAL is a multi-disciplinary open access archive for the deposit and dissemination of scientific research documents, whether they are published or not. The documents may come from teaching and research institutions in France or abroad, or from public or private research centers.
L'archive ouverte pluridisciplinaire HAL, est destinée au dépôt et à la diffusion de documents scientifiques de niveau recherche, publiés ou non, émanant des établissements d'enseignement et de recherche français ou étrangers, des laboratoires publics ou privés. 


\section{Ionic Schiff Base Dioxidomolybdenum(VI) Complexes as Catalysts in Ionic Liquid Media for Cyclooctene Epoxidation}

Christine Bibal, ${ }^{[a][b] *}$ Jean-Claude Daran, ${ }^{[b]}$ Simon Deroover ${ }^{[a][b]}$ and Rinaldo Poli ${ }^{[b][c]}$

${ }^{a}$ Université de Toulouse, Université Paul Sabatier, Institut Universitaire de Technologie A, Département de Chimie. Avenue Georges Pompidou, 81104 Castres Cedex, France.

${ }^{\mathrm{b}}$ CNRS; LCC (Laboratoire de Chimie de Coordination); Université de Toulouse; UPS, INPT; 205, route de Narbonne, F-31077 Toulouse, France.

${ }^{\mathrm{c}}$ Institut Universitaire de France, 103, bd Saint-Michel, 75005 Paris, France.

*Corresponding author. Phone: (0033)563621155; fax: (0033)563621585.

E-mail address: christine.bibal@iut-tlse3.fr 


\begin{abstract}
The preparation of several new molybdenum(VI) complexes containing Schiff base ligands tagged with sulfonate functionalities is presented. The title compounds have been characterized by standard analytical methods including NMR, IR, and mass spectroscopy. Xray structures of the $\mathrm{N}$-salicylidene-2-aminophenolate dioxidomolybdenum complexes bearing sulfonato groups on the salicylidene moiety (as the sodium and ammonium salts) are described herein accompanied by the structural characterization of the N-salicylidene-2aminoethanolate sulfonate Schiff base ligand. The activity of the ionic catalysts for cyclooctene epoxidation is shown in different room temperature ionic liquids (i.e. $\left.[\mathrm{BMIM}]\left[\mathrm{NTf}_{2}\right]\left(\mathrm{NTf}_{2}^{-}=\left(\mathrm{CF}_{3} \mathrm{SO}_{2}\right)_{2} \mathrm{~N}^{-}\right),[\mathrm{BMIM}]\left[\mathrm{CF}_{3} \mathrm{SO}_{3}\right],[\mathrm{EMIM}]\left[\mathrm{CH}_{3} \mathrm{C}_{6} \mathrm{H}_{4} \mathrm{SO}_{3}\right]\right)$.
\end{abstract}




\section{Introduction}

The use of two-phase solvent systems, especially those based on water-soluble ligands and their metal complexes [1], has emerged in the last decade as a synthetic strategy for homogeneous catalysis. In this respect, room temperature Ionic Liquids (ILs) as solvents have proved to be mainly useful for these types of two-phase catalytic reactions [2]. Particularly, the interest in ILs as alternatives to organic solvents has been growing with regards to economic and ecological concerns [3]. However, ILs have only recently been applied to metal transition catalysis [4] with the benefit of a convenient catalyst separation, hence, recovery/recycling procedure. Catalyzed oxidations in ILs have resulted in a few processes that are more efficient than those carried out in organic solvents [5]. The efficiency of the catalyst/ILs system is strongly dependent on the nature of the ILs. The rationalization of its role in association with the catalyst remains an unexplored research area. Nevertheless, Dupont et al have already shown the "non-innocent" nature of ILs under certain reaction conditions [6].

In oxidation catalysis, the choice of a suitable ligand is often delicate because it must also be resistant towards the oxidant. The most efficient Jacobsen's and Katsuki's catalysts have evolved as standard reagents for asymmetric epoxidation reactions due to the ease of the Schiff base synthetic generation [7]. It was found that in some cases the activity of both catalysts was increased by adding ionic liquids to the reaction mixture [8]. However, decreasing yields were obtained during successive runs due to either catalyst decomposition under basic conditions or loss of material in the work up process. As a result, a better immobilized catalyst in the IL phase with the adequate ionic structure would permit developing a convenient experimental procedure for a suitable biphasic reusable catalytic system. 
Among different families of metal complexes used as oxidation catalysts, complexes of the type $\mathrm{Mo}(\mathrm{VI}) \mathrm{O}_{2} \mathrm{~L}$ have received special attention [9]. With the coordinating ligand $\mathrm{L}$ functioning as a mono-, bi-, tri-, or tetradentate ligand, these molecular constructs have already been shown to be effective catalysts or catalyst precursors for olefin epoxidation. Representative members of that kind possess the following general formula: $\left[\mathrm{MoO}_{2} \mathrm{X}_{2}\left(\mathrm{~L}^{1}\right)_{\mathrm{n}}\right]$, $\left[\mathrm{MoO}_{2} \mathrm{X}\left(\mathrm{L}^{2}\right)\left(\mathrm{L}^{1}\right)_{\mathrm{n}}\right]$ and $\left[\mathrm{MoO}_{2}\left(\mathrm{~L}^{2}\right)_{2}\left(\mathrm{~L}^{1}\right)_{\mathrm{n}}\right]\left(\mathrm{X}=\mathrm{Cl}, \mathrm{Br}, \mathrm{CH}_{3}, \mathrm{OR}\right.$ etc; $\mathrm{L}=$ mono or bidentate neutral $\left(\mathrm{L}^{1}\right)$ or anionic $\left(\mathrm{L}^{2}\right)$ ligands with nitrogen, oxygen/sulfur donors) [10]. Related versions with multidentate dianionic ligands are also used. Specifically, dioxidomolybdenum(VI) complexes bearing tetradentate dianionic salen ligands are promising reagents for this type of chemical transformation reaction [11]. Complexes containing tridentate dianionic Schiff base ligands of the type $\mathrm{MoO}_{2}(\mathrm{~L})(\mathrm{D})(\mathrm{D}=$ solvent $)$ possess a labile ligand D suitable for substrate activation and oxidant uptake [12]. However, the use of dioxidomolybdenum(VI) complexes in combination with ILs is limited and has only been described rarely in literature to date [13].

One synthetic strategy to gain an enhanced solubility of the catalyst in ILs may be accomplished by introducing ionic functionalities on the ligand periphery. Synthetically modified $\mathrm{MoO}_{2}(\mathrm{~L})$ complexes bearing anionic sulfonato $\left(-\mathrm{SO}_{3}{ }^{-}\right)$functionalities may yield novel candidates for olefin epoxidation. Such compounds would not only be able to activate chemical bonds but also allow for reactivity in polar media with the additional benefit to performing catalytic applications in green media such as ILs and water, the latter probably being the most environment-friendly medium.

It is generally accepted that the Lewis acidity of dioxidomolybdenum(VI) complexes is one of the most important characteristics that determine catalytic performance in olefin epoxidation [14]. High turnover frequencies are often associated with a low electron density at the metal centre. Therefore, introducing an electron-withdrawing functionality such as sulfonate anions onto the salicylidene ring of the complex may hold potential for a better 
efficiency of the catalyst. Herein, we present the synthesis and the characterization of dioxidomolybdenum(VI) complexes with sulfonated tridentate Schiff base ligands. These complexes of the type $\mathrm{MoO}_{2} \mathrm{~L}$, L being a tridentate trianionic Schiff base ligand [sulfonated $\mathrm{N}$-salicylidene-2-aminophenolate $\left(\mathrm{sSAP}^{3-}\right)$ or $\mathrm{N}$-salicylidene-2-aminoethanolate $\left.\left(\mathrm{sSAE}^{3-}\right)\right]$, have been characterized by standard spectroscopic methods. These ligands are sulfonated versions of well known $\mathrm{SAE}^{2-}$ and $\mathrm{SAP}^{2-}$ Schiff bases [15].

Preliminary results for cyclooctene epoxidation in an aqueous medium and in different ILs (ie $\left.[\mathrm{BMIM}]\left[\mathrm{NTf}_{2}\right]\left(\mathrm{NTf}_{2}{ }^{-}=\left(\mathrm{CF}_{3} \mathrm{SO}_{2}\right)_{2} \mathrm{~N}^{-}\right),[\mathrm{BMIM}]\left[\mathrm{CF}_{3} \mathrm{SO}_{3}\right],[\mathrm{EMIM}]\left[\mathrm{CH}_{3} \mathrm{C}_{6} \mathrm{H}_{4} \mathrm{SO}_{3}\right]\right)$ with $t$-butyl-hydroperoxide (TBHP) as oxidant will be presented.

\section{Experimental}

\subsection{Materials and methods}

All reactions were performed in air. Salicylaldehyde, 2-aminophenol, 2-amino-1ethanol, tetrabutylammonium bromide and $\mathrm{MoO}_{2}(\mathrm{acac})_{2}(\mathrm{acac}=$ acetylacetonate $)$ were purchased from commercial sources as well as the ionic liquids [BMIM][ $\left.\mathrm{NTf}_{2}\right]$ (from Solvionic), $\quad[\mathrm{BMIM}]\left[\mathrm{CF}_{3} \mathrm{SO}_{3}\right]$ and $[\mathrm{EMIM}]\left[\mathrm{CH}_{3} \mathrm{C}_{6} \mathrm{H}_{4} \mathrm{SO}_{3}\right]$ (from Aldrich). Sodium salicylaldehyde-5-sulfonate was synthesized according to literature procedure [16]. ${ }^{1} \mathrm{H}$ and ${ }^{13} \mathrm{C}$ NMR spectra were recorded at $200.1 \mathrm{MHz}$ and $50.3 \mathrm{MHz}$ respectively on a Bruker Avance DPX-200 spectrometer. Infrared spectra were recorded on a Mattson Genesis II FTIR spectrometer using $\mathrm{KBr}$ pellets as IR matrix. The catalytic reaction products were analyzed by gas chromatography on an Agilent 6890A chromatograph equipped with FID detector, a HP5-MS capillary column $(30 \mathrm{~m} \times 0.25 \mathrm{~mm} \times 0.25 \mu \mathrm{m})$ and automatic sampling corresponding to Figure 4 and Figure 6, on a Fisons GC 8000 chromatograph equipped with FID detector and with a SPB-5 capillary column $(30 \mathrm{~m} \times 0.32 \mathrm{~mm} \times 0.25 \mu \mathrm{m})$ corresponding 
to Figure 5. Elemental analyses were carried out by the analytical service of the Laboratory of Coordination Chemistry. The analytical results were difficult to interpret because of the uncertainty in the number of water molecules for the sodium salts (compounds 1-4) and possible incomplete combustion (all compounds). The compounds purity is shown by the quality of the NMR spectra (Supporting Information).

\subsection{Preparation of Schiff base ligand $\mathrm{NaH}_{2} \mathrm{SSAP}, \mathbf{1}$}

Sodium salicylaldehyde-5-sulfonate $(1,3 \mathrm{~g}, 5,80 \mathrm{mmol})$ and 2-aminophenol (0,63 g, $5,80 \mathrm{mmol})$ were combined in $30 \mathrm{ml}$ of water/ethanol $(1: 1)$ and refluxed for $4 \mathrm{~h}$ at $60^{\circ} \mathrm{C}$. The yellow precipitate was filtered, washed with diethyl ether and dried in air to afford $1.24 \mathrm{~g}$ of the ligand 1. Yield: 68\%. ${ }^{1} \mathrm{H}$ NMR (DMSO- $\mathrm{d}_{6}, \delta(\mathrm{ppm})$ ):6.84-7.87 (m, 7H, H aryl); 9.01 (s, $1 \mathrm{H}, \mathrm{CH}=\mathrm{N}) ; 9.78(\mathrm{~s}, 1 \mathrm{H}, \mathrm{OH}) ; 14.06(\mathrm{~s}, 1 \mathrm{H}, \mathrm{OH}) .{ }^{13} \mathrm{C}$ NMR (DMSO-d $\left.6, \delta(\mathrm{ppm})\right): 116.04$, $116.54,118.03,119.52,119.65,128.18,129.56,130.45,134.56,139.20$ (C aryl); 151.17 (C$\mathrm{OH}) ; 161.24(\mathrm{C}-\mathrm{OH}) ; 161.39(\mathrm{CH}=\mathrm{N})$. Selected IR bands $\left(\mathrm{KBr}, \mathrm{cm}^{-1}\right)$ : 3528(br), 3468(br), 3407(br) $v(\mathrm{OH}) ; 2927(\mathrm{~m}), 2853(\mathrm{~m}) v(\mathrm{C}-\mathrm{H}) ; 1621(\mathrm{~s}) v(\mathrm{C}=\mathrm{N}), 1603(\mathrm{sh}) ; 1523(\mathrm{~s}), 1470(\mathrm{~s})$, 1374(m), 1340(m); 1277(m), 1242(m), 1223(m); 1179(s), 1141(m), 1107(s), 1030(s) v( $\left.\mathrm{SO}_{3}{ }^{-}\right)$. FAB-MS: negative mode $\left(\mathrm{M}=292, \mathrm{~A}^{-}\right),\left(\mathrm{M}=607,\left[2 \mathrm{~A}^{-}+\mathrm{Na}^{+}\right]^{-}\right)$.

\subsection{Preparation of Schiff base ligand $\mathrm{NaH}_{2} \mathrm{SSAE}, \mathbf{2}$}

Sodium salicylaldehyde-5-sulfonate (1,07 g, 4,77 mmol) and amino-ethanol (0,29 $\mathrm{mL}$, $4,77 \mathrm{mmol})$ were combined in $20 \mathrm{ml}$ of water/ethanol $(1: 1)$ and refluxed for $4 \mathrm{~h}$ at $60^{\circ} \mathrm{C}$. The crude solid obtained after evaporation of the solvents was recrystallized from absolute ethanol. Yield: 39\%. ${ }^{1} \mathrm{H}$ NMR (DMSO-d $6, \delta(\mathrm{ppm})$ ): $3.64\left(\mathrm{~m}, 4 \mathrm{H}, \mathrm{CH}_{2}\right) ; 4.81(\mathrm{~s}, 1 \mathrm{H}, \mathrm{OH})$; 
$6.76\left(\mathrm{~d},{ }^{3} \mathrm{~J}_{\mathrm{HH}}=8.6 \mathrm{~Hz}, 1 \mathrm{H}, \mathrm{H}\right.$ aryl $) ; 7.52\left(\mathrm{~d},{ }^{3} \mathrm{~J}_{\mathrm{HH}}=8.6 \mathrm{~Hz}, 1 \mathrm{H}, \mathrm{H}\right.$ aryl $) ; 7.66(\mathrm{~s}, 1 \mathrm{H}, \mathrm{H}$ aryl $)$;

$8.54(\mathrm{~s}, 1 \mathrm{H}, \mathrm{CH}=\mathrm{N}) ; 13.86(\mathrm{~s}, 1 \mathrm{H}, \mathrm{OH}) .{ }^{13} \mathrm{C} \mathrm{NMR}\left(\mathrm{DMSO}_{-} \mathrm{d}_{6}, \delta(\mathrm{ppm})\right): 60.35,60.54\left(\mathrm{CH}_{2}\right)$; 116.06, 116.91, 128.90, 129.99, 138.59 (C aryl); 162.05 (C-O); $166.61(\mathrm{CH}=\mathrm{N})$. Selected IR bands $\left(\mathrm{KBr}, \mathrm{cm}^{-1}\right): 3488(\mathrm{br}), 3395(\mathrm{br}) v(\mathrm{OH}) ; 2947(\mathrm{~m}), 2922(\mathrm{~m}), 2889(\mathrm{~m}) v(\mathrm{C}-\mathrm{H}) ; 1659(\mathrm{~s})$ $v(\mathrm{C}=\mathrm{N}), 1610(\mathrm{~s}) ; 1518(\mathrm{~s}), 1450(\mathrm{~s}), 1407(\mathrm{~m}), 1385(\mathrm{~m}), 1361(\mathrm{~m}), 1324(\mathrm{~m}), 1294(\mathrm{~m}), 1220(\mathrm{~s})$; 1188(s); 1172(s), 1112(s), 1082(m), 1038(s) v( $\left.\mathrm{SO}_{3}{ }^{-}\right)$. FAB-MS: negative mode $\left(\mathrm{M}=244, \mathrm{~A}^{-}\right)$, $\left(\mathrm{M}=511,\left[2 \mathrm{~A}^{-}+\mathrm{Na}^{+}\right]^{-}\right),\left(\mathrm{M}=778,\left[3 \mathrm{~A}^{-}+2 \mathrm{Na}^{+}\right]^{-}\right)$.

\subsection{Synthesis of complex $\mathrm{MoO}_{2}(s S A P) N a, 3$}

A solution of 1 (480 mg, $1.52 \mathrm{mmol})$ and $\mathrm{MoO}_{2}(\mathrm{acac})_{2}(497 \mathrm{mg}, 1.52 \mathrm{mmol})$ in absolute ethanol $(35 \mathrm{~mL})$ was refluxed for $2 \mathrm{~h}$. The obtained orange precipitate was then filtered and dried in air. Yield: 55\%. ${ }^{1} \mathrm{H}$ NMR (DMSO-d $6, \delta(\mathrm{ppm})$ ): 6.82-8.09 (m, 7H, H aryl); $9.36(\mathrm{~s}, 1 \mathrm{H}, \mathrm{CH}=\mathrm{N}) .{ }^{13} \mathrm{C}$ NMR (DMSO-d $\left.6, \delta(\mathrm{ppm})\right): 116.77,117.32,118.41,120.60$, 120.90, 130.21, 132.36, 132.97, 135.73, 141.03 (C aryl); 156.92 (C-O); 160.16 (C-O); 161.33 $(\mathrm{CH}=\mathrm{N})$. Selected IR bands $\left(\mathrm{KBr}, \mathrm{cm}^{-1}\right): 3626(\mathrm{~m}), 3546(\mathrm{~m}), 3465(\mathrm{br}), 3118(\mathrm{~m}) v(\mathrm{OH})$; 2924(m), 2853(m) v(C-H); 1617(s) v(C=N); 1589(m), 1544(m), 1488(s), 1464(m), 1372(m), 1296(m), 1262(s), 1247(m); 1174(s), 1109(s), 1047(s) v( $\left.\mathrm{SO}_{3}^{-}\right)$; 933(s), 910(s) v(Mo=O). FABMS: negative mode $\left(M=420, A^{-}\right)$.

\subsection{Synthesis of complex $\mathrm{MoO}_{2}(\mathrm{SSAE}) \mathrm{Na}, \mathbf{4}$}

The same procedure that was applied to yield complex $\mathrm{MoO}_{2}(\mathrm{sSAP}) \mathrm{Na} \mathbf{3}$ was used for the synthesis of the analogue complex 4. Yield: 71\%. ${ }^{1} \mathrm{H}$ NMR (DMSO- $\left.\mathrm{d}_{6}, \delta(\mathrm{ppm})\right): 4.01(\mathrm{~m}$, $\left.2 \mathrm{H}, \mathrm{CH}_{2}\right) ; 4.41\left(\mathrm{~m}, 2 \mathrm{H}, \mathrm{CH}_{2}\right) ; 6.82\left(\mathrm{~d},{ }^{3} \mathrm{~J} \mathrm{HH}=8.5 \mathrm{~Hz}, 1 \mathrm{H}, \mathrm{H}\right.$ aryl $) ; 7.66\left(\mathrm{~d} \times \mathrm{d},{ }^{3} \mathrm{~J} \mathrm{HH}=8.5 \mathrm{~Hz}\right.$, ${ }^{3} \mathrm{~J}_{\mathrm{HH}}=1.7 \mathrm{~Hz}, 1 \mathrm{H}, \mathrm{H}$ aryl $) ; 7.81\left(\mathrm{~m}, 1 \mathrm{H}, \mathrm{H}\right.$ aryl); $8.81(\mathrm{~s}, 1 \mathrm{H}, \mathrm{CH}=\mathrm{N}) .{ }^{13} \mathrm{C}$ NMR (DMSO-d 6 , 
$\delta(\mathrm{ppm})): 60.95\left(\mathrm{CH}_{2}-\mathrm{N}\right), 71.59\left(\mathrm{CH}_{2}-\mathrm{O}\right) ; 118.72,119.52,130.97,132.14,139.68(\mathrm{C}$ aryl); $161.43(\mathrm{C}-\mathrm{O})$; $164.11(\mathrm{CH}=\mathrm{N})$. Selected IR bands $\left(\mathrm{KBr}, \mathrm{cm}^{-1}\right): 3450(\mathrm{br}) v(\mathrm{OH}) ; 2953(\mathrm{~m})$, 2927(m), 2867(m) v(C-H); 1640(s) v(C=N), 1605(m); 1549(m), 1468(m), 1373(m), 1301(m), 1207(m); 1170(m), 1118(s), 1043(s), 1036(s) v( $\left.\mathrm{SO}_{3}^{-}\right) ; 936(\mathrm{~m}), 911(\mathrm{~s}) v(\mathrm{Mo}=\mathrm{O}), 896(\mathrm{sh})$. FAB-MS: negative mode $\left(\mathrm{M}=372, \mathrm{~A}^{-}\right)$.

\subsection{Synthesis of complex $\mathrm{MoO}_{2}(\mathrm{SSAP}) \mathrm{NBu}, \mathbf{5}$}

Tetrabutylammonium bromide $(74 \mathrm{mg}, 0,23 \mathrm{mmol})$ was added in small portions to complex 3 (105 mg, $0.20 \mathrm{mmol}$ ) which was solubilized in $1 \mathrm{ml}$ of water. The orange precipitate that appeared immediately after addition was filtered. Yield: $68 \% .{ }^{1} \mathrm{H}$ NMR $\left(\mathrm{DMSO}_{6}, \delta(\mathrm{ppm})\right): 0.92\left(\mathrm{t},{ }^{3} \mathrm{~J}_{\mathrm{HH}}=7 \mathrm{~Hz}, 12 \mathrm{H}, \mathrm{CH}_{3}\right) ; 1.29\left(\mathrm{q},{ }^{3} \mathrm{~J}_{\mathrm{HH}}=7 \mathrm{~Hz}, 8 \mathrm{H}, \mathrm{CH}_{2}\right) ; 1.55$ $\left(\mathrm{m}, 8 \mathrm{H}, \mathrm{CH}_{2}\right) ; 3.15\left(\mathrm{~m}, 8 \mathrm{H}, \mathrm{NCH}_{2}\right) ; 6.81-8.09$ (m, 7H, H aryl); 9.35 (s, $\left.1 \mathrm{H}, \mathrm{CH}=\mathrm{N}\right) .{ }^{13} \mathrm{C}$ NMR (DMSO-d $6, \delta(\mathrm{ppm})): 13.59,19.29,23.13,57.57,116.73,117.29,118.33,120.55$, 120.84, 130.14, 132.31, 132.94, 135.71, 141.28 (C aryl); 156.94 (C-O); 160.14 (C-O); 161.0 $(\mathrm{CH}=\mathrm{N})$. Selected IR bands $\left(\mathrm{KBr}, \mathrm{cm}^{-1}\right): 2960(\mathrm{~m}), 2931(\mathrm{sh}), 2872(\mathrm{~m}) \quad v(\mathrm{C}-\mathrm{H}) ; 1617(\mathrm{~s})$ $v(\mathrm{C}=\mathrm{N}), 1600(\mathrm{sh}) ; 1585(\mathrm{~m}), 1546(\mathrm{~m}), 1491(\mathrm{sh}), 1479(\mathrm{~m}), 1467(\mathrm{~m}), 1384(\mathrm{~m}), 1367(\mathrm{~m}) ;$

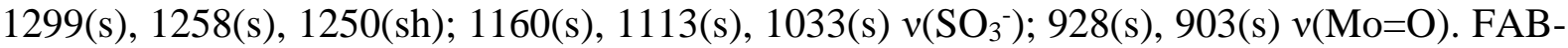
MS: negative mode $\left(M=420, A^{-}\right)$; positive mode $\left(M=242, \mathrm{NBu}_{4}{ }^{+}\right)$.

\subsection{Catalytic epoxidation of cyclooctene by complexes 3-5 in IL media}

The catalytic reactions were performed in air in a reaction flask, equipped with a magnetic stirrer and immersed into a thermostated bath. A mixture of catalyst (70 $\mu$ mol, 0.01 eq), cyclooctene $(0.80 \mathrm{~g}, 7.3 \mathrm{mmol}, 1 \mathrm{eq})$, dodecane as internal standard $(0.75 \mathrm{~g}, 1 \mathrm{~mL})$ with $0.5 \mathrm{ml}$ of ionic liquid equilibrated in air was stirred for $15 \mathrm{~min}$ at $55^{\circ} \mathrm{C}$. At this temperature, 
anhydrous $t$-butyl hydroperoxide (5.5 $\mathrm{M}$ in $n$-decane, $2.1 \mathrm{eq}, 15.4 \mathrm{mmol}, 2.8 \mathrm{ml})$ was added (start of the reaction). Aliquots of the reaction medium were withdrawn at certain time intervals to monitor the reaction by quantitative GC analysis. The samples were treated with $\mathrm{MnO}_{2}$ to remove peroxides and diluted with $1 \mathrm{ml}$ of diethyl ether. The resulting slurry was filtered on silica gel, eluted with $10 \mathrm{ml}$ of diethyl ether and the filtrate was injected in the GC. The conversion of cyclooctene, and the formation of cyclooctene oxide were calculated according to calibration curves $\left(\mathrm{r}^{2}=0.999\right)$.

\subsection{Catalytic epoxidation of cyclooctene by complex 3 with TBHP (70\% in water)}

The same procedure as for the epoxidation in IL media was employed with the following quantities of reactants: catalyst $3(65 \mathrm{mg}, 0.127 \mathrm{mmol}, 0.007 \mathrm{eq})$, cyclooctene (2.6 $\mathrm{mL}, 18.8 \mathrm{mmol}, 1 \mathrm{eq})$, TBHP (70\% in water, $10 \mathrm{~mL}, 74.4 \mathrm{mmol}, 4 \mathrm{eq})$ and dodecane (150 mg) as internal standard. The temperature in this experiment was adjusted to $80^{\circ} \mathrm{C}$.

\subsection{General procedure for the recycling of the catalyst 3 in [BMIM][NTf 2$]$}

The epoxidation was performed under the same reaction conditions as described in paragraph 2.7 for catalyst 3 (70 $\mu \mathrm{mol}, 0.01 \mathrm{eq})$ in cyclooctene $(0.82 \mathrm{~g}, 1 \mathrm{eq})$, dodecane $(0.83$ $\mathrm{g}), 0.5 \mathrm{ml}$ of [BMIM][NTf 2$]$ and $t$-butyl hydroperoxide $(5.5 \mathrm{M}$ in $n$-decane, $2.8 \mathrm{ml})$. The upper organic phase was separated and the IL phase was extracted with pentane $(4 * 5 \mathrm{~mL})$. The collected organic layers were assembled and injected into the GC to evaluate the residual cyclooctene fraction and the cyclooctene oxide yield. The IL phase was then dried under vacuum for $1.5 \mathrm{~h}$ to remove traces of pentane and $t \mathrm{BuOH}$ formed in the catalytic run. The IL phase was reused in the consecutive cycle with a new charge of cycloooctene, dodecane and 
TBHP as it was in the first cycle. The same extraction procedure was re-applied for each consecutive cycle.

\subsection{X-ray crystallography}

A single crystal of each compound was mounted under inert perfluoropolyether at the tip of a glass fibre and cooled in the cryostream of either an Oxford-Diffraction XCALIBUR or a Bruker APEXII CCD diffractometer. Data were collected using the monochromatic MoK $\alpha$ radiation $(\lambda=0.71073)$. The structures were solved by direct methods (SIR97) [17] and refined by least-squares procedures on $F^{2}$ using SHELXL-97 [18]. All H atoms attached to carbon were introduced in idealised positions and treated as riding on their parent atoms in the calculations. In the ligand structure the $\mathrm{H}$ atoms attached to nitrogen and oxygen atoms were located in difference Fourier synthesis. For Molecule 2 (atoms O24 and N25), the H atom was clearly identified as bonded to atom N25 with no significant electron density on atom O24. For Molecule 1, on the other hand, two smaller electron densities were located near the atoms $\mathrm{O} 14$ and N15, indicating the coexistence of both expected tautomers. The two $\mathrm{H}$ atoms had equivalent peak height in the difference Fourier map and they were therefore introduced with occupancy factors of 0.50 each, which were not refined. These atoms were treated as riding on their parent atoms. In compound $\mathbf{3}$, the $\mathrm{H}$ atoms attached to water molecules were located in difference Fourier syntheses and their coordinates were initially refined using $\mathrm{O}-\mathrm{H}[0.82(1) \AA]$ and $\mathrm{H} \cdots \mathrm{H}[1.39(2) \AA]$ restraints. In the last stage of refinement, they were treated as riding with $\mathrm{U}_{\mathrm{iso}}=1.5 \mathrm{U}_{\mathrm{eq}}(\mathrm{O})$. The drawing of the molecules was realised with the help of ORTEP3 [19]. Crystal data and refinement parameters are shown in Table 1.

Table 1. Crystal data and structure refinement. 


\begin{tabular}{|c|c|c|c|}
\hline Empirical formula & $\mathrm{C}_{11} \mathrm{H}_{19} \mathrm{~N}_{2} \mathrm{O}_{6} \mathrm{~S}$ & $\mathrm{C}_{13} \mathrm{H}_{16} \mathrm{MoNNaO}_{11} \mathrm{~S}$ & $\mathrm{C}_{29} \mathrm{H}_{44} \mathrm{MoN}_{2} \mathrm{O}_{7} \mathrm{~S}$ \\
\hline Formula weight & 307.34 & 513.26 & 660.66 \\
\hline Temperature, $\mathrm{K}$ & $180(2)$ & $180(2)$ & $180(2)$ \\
\hline Wavelength, $\AA$ & 0.71073 & 0.71073 & 0.71073 \\
\hline Crystal system & Triclinic & Triclinic & Monoclinic \\
\hline Space group & $\mathrm{P}-1$ & P-1 & $\mathrm{P} 2{ }_{1} / \mathrm{n}$ \\
\hline $\mathrm{a}, \AA$ & $8.9888(3)$ & $7.4591(3)$ & $15.1111(6)$ \\
\hline $\mathrm{b}, \AA$ & $11.4975(15)$ & $8.8059(3)$ & $9.8013(4)$ \\
\hline $\mathrm{c}, \AA$ & $13.9128(4)$ & $14.8734(7)$ & $21.0181(8)$ \\
\hline$\alpha,{ }^{\circ}$ & $104.168(2)$ & $102.324(2)$ & 90.0 \\
\hline$\beta,^{\circ}$ & $91.369(2)$ & $97.866(2)$ & $101.622(4)$ \\
\hline$\gamma,{ }^{\circ}$ & $93.383(2)$ & 106.453 & 90.0 \\
\hline Volume, $\AA^{3}$ & $1391.51(8)$ & $894.82(6)$ & $3049.1(2)$ \\
\hline $\mathrm{Z}$ & 4 & 2 & 4 \\
\hline $\mathrm{D}$ (calcd), $\mathrm{Mg} / \mathrm{m}^{3}$ & 1.462 & 1.905 & 1.439 \\
\hline Abs. coeff., $\mathrm{mm}^{-1}$ & 0.257 & 0.935 & 0.546 \\
\hline $\mathrm{F}(000)$ & 648 & 516 & 1384 \\
\hline Crystal size, $\mathrm{mm}^{3}$ & $0.88 \times 0.64 \times 0.24$ & $0.46 \times 0.246 \times 0.104$ & $0.383 \times 0.101 \times 0.045$ \\
\hline Theta range, ${ }^{\circ}$ & 2.64 to $26.08^{\circ}$. & 1.43 to 31.00 & 2.58 to 28.28 \\
\hline Reflts collected & 35600 & 20568 & 26894 \\
\hline Unique reflts [R(int)] & $8139(0.0222)$ & $5642(0.0293)$ & $7539(0.0556)$ \\
\hline Completeness, $\%$, & 99.8 & $98.9 \%$ & 99.8 \\
\hline Abs. correction & Multi-scan & Multi-scan & Multi-scan \\
\hline Max. / min. abs. & $1.0 / 0.812$ & $1.0 / 0.8439$ & 1.0 and 0.75026 \\
\hline Data / restr. / param. & 8139 / 0 / 367 & $5642 / 0 / 244$ & 7539 / 0 / 365 \\
\hline GOF on $\mathrm{F}^{2}$ & 1.070 & 1.166 & 0.909 \\
\hline $\mathrm{R}, \mathrm{wR} 2[\mathrm{I}>2 \backslash \mathrm{s}(\mathrm{I})]$ & $0.0323,0.0891$ & $0.0240,0.0692$ & $0.0346,0.0723$ \\
\hline R, wR2 (all data) & $0.0405,0.0972$ & $0.0289 / 0.0784$ & $0.0710,0.0808$ \\
\hline Resid. density, e. $\AA^{-3}$ & $0.451 /-0.458$ & $0.817 /-1.094$ & $0.615 /-0.795$ \\
\hline
\end{tabular}

\section{Results and discussion}

3.1. Synthesis of sulfonated tridentate Schiff base ligands and the corresponding ionic $\mathrm{MoO}_{2}(L)$ complexes 
The preparation of mono and di-sulfonated tridentate "ONO" salicylaldimine ligands has already been described in literature by Evans and Chakravorty [20]. Surprisingly, little is known for these molecules with respect to detailed characterization data such as X-ray structures, NMR and mass spectroscopy. Herein we will present the preparation of sulfonated Schiff base ligands $\mathrm{NaH}_{2} \mathrm{~L}, \mathrm{~L}$ being $\mathrm{N}$-salicylidene-2-aminophenolate sulfonate (sSAP ${ }^{3-}$ ), 1, or N-salicylidene-2-aminoethanolate sulfonate ( $\left.\mathrm{SSAE}^{3-}\right), 2$, and their complexation onto the molybdenum metal, resulting in complexes $\mathbf{3}$ and $\mathbf{4}$ respectively, see Scheme 1.
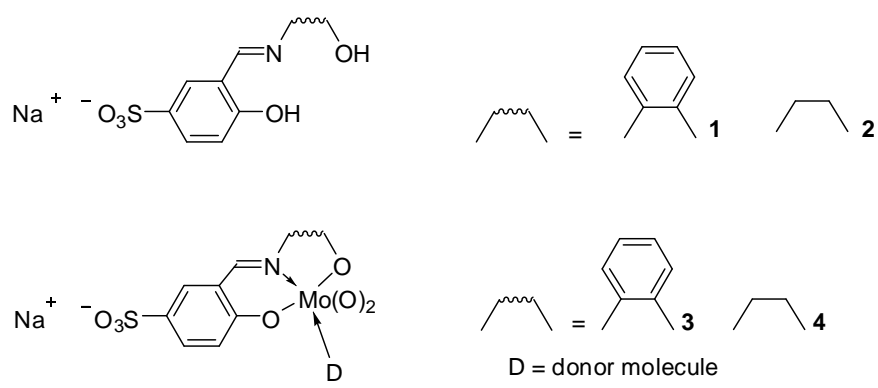

Scheme 1. Sulfonated tridentate Schiff base ligands $\mathrm{NaH}_{2} \mathrm{~L}$ and the corresponding cisdioxidomolydenum(VI).

The synthetic methodology already described by Evans and co-workers [20] consists of the condensation of the water soluble salicylaldehyde-5-sulfonate precursor with different amino-alcohols or amino-acids of the type $\mathrm{RNH}_{2}$ (scheme 2).

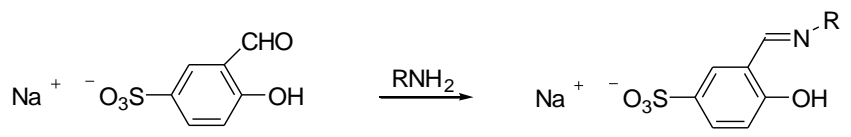

Scheme 2. General procedure for the preparation of sulfonated tridentate Schiff base. 
Following this procedure, we have synthesized the two types of sulfonated Schiff base ligands $\mathrm{NaH}_{2} \mathrm{~L}$, sodium $\mathrm{N}$-salicylidene-2-aminophenolate sulfonate $\left(\mathrm{NaH}_{2} \mathrm{SSAP}\right)$ or sodium $\mathrm{N}$-salicylidene-2-aminoethanolate sulfonate $\left(\mathrm{NaH}_{2} \mathrm{SSAE}\right)$ by reacting the sulfonated salicylaldehyde sodium salt with commercially available 2-aminophenol and 2-aminoethanol respectively. The corresponding dioxidomolydenum(VI) complexes with general formula $\mathrm{NaMoO}_{2}(\mathrm{~L}) \mathrm{D}$ have been isolated after reacting $\mathrm{NaH}_{2} \mathrm{~L}$ with the molybdenum precursor $\mathrm{MoO}_{2}(\mathrm{acac})_{2}$ in refluxing ethanol as shown in scheme 3.

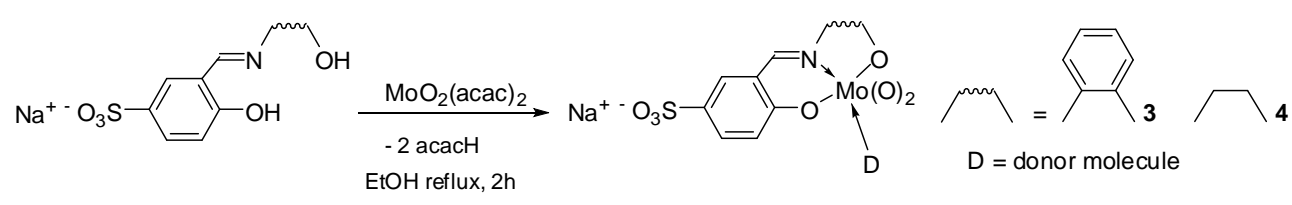

Scheme 3. Preparation of sulfonated tridentate Schiff base dioxidomolybdenum(VI) complexes.

For the cis-dioxidomolydenum(VI) complex $\mathbf{3}$, the filtered orange precipitate turns reddish upon drying in air. Single crystals were obtained by slow solvent evaporation of a concentrated ethanol solution left at room temperature. The nature of the donor molecule for the $\mathrm{NaMoO}_{2} \mathrm{LD}$ structure in the solid state could be determined by performing a single crystal X-ray diffraction study. The structure reveals that the sixth coordination site of molybdenum is completed by a sulfonato oxygen atom from an adjacent molecule, indicated as D in Scheme 3 (see X-ray diffraction analysis section).

A cation exchange reaction was performed in the case of the dioxidomolybdenum complex 3 bearing the $\mathrm{N}$-salicylidene-2-aminophenolate sulfonato ligand (scheme 4). The solubility of $\mathbf{3}$ in water and its good stability against hydrolysis of the $-\mathrm{CH}=\mathrm{N}$ functionality allowed the reaction to occur in this medium at room temperature. The resulting ammonium complex 5 precipitated from the reaction medium and filtration allowed isolation of the 
compound in good purity. Crystals grown from a concentrated solution of $\mathbf{5}$ in ethanol were shown by single crystal X-ray diffraction to be composed of the desired salt with a noninteracting ammonium cation. Like in the structure of the analogue sodium salt $\mathbf{3}$, the coordination sphere around the molybdenum atom in the solid state is completed by a sulfonato oxygen atom from an adjacent molecule (see X-ray diffraction analysis section).
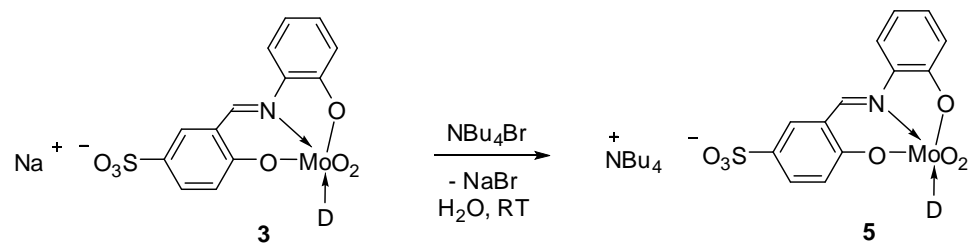

Scheme 4. Cation metathesis of sodium salt 3 with ammonium bromide affording the ammonium dioxidomolybdenum complex $\mathbf{5}$.

\subsection{Spectral features}

In the ${ }^{1} \mathrm{H}$ NMR spectra of the Schiff base ligands $\mathrm{NaH}_{2} \mathrm{~L} \mathbf{1}$ and 2, the phenol $\mathrm{OH}$ proton resonances in para position to the sulfonato functionality are shifted downfield with respect to classic phenol proton signals. The $\mathrm{OH}$ signals disappear in the ${ }^{1} \mathrm{H}$ NMR spectra of the complexes indicating the effective binding of the ligand through a dianionic "ONO" tridentate mode. Furthermore, the singlet of the imine carbon proton shifts downfield compared to the corresponding signal in the free ligands through coordination of the nitrogen onto the molybdenum cation. It is also worth mentioning that in the ${ }^{1} \mathrm{H}$ NMR of the sSAE dioxidomolybdenum complex $\mathbf{4}$, the ethylene resonance is resolved into two distinguishable triplet signals in comparison to the corresponding single multiplet signal in the sulfonated $\mathrm{NaH}_{2} \mathrm{SSAE}$ ligand. No ethanol molecule (used as solvent in the synthesis) was observed as D ligand (Scheme 1) in the ${ }^{1} \mathrm{H}$ NMR spectra of 3 and $\mathbf{4}$ in DMSO- $\mathrm{d}_{6}$ and $\mathrm{D}_{2} \mathrm{O}$. This is in contrast 
with the described structures of the corresponding neutral $\mathrm{MoO}_{2} \mathrm{LD}$ complexes (with $\mathrm{L}=\mathrm{SAP}$ or SAE) obtained by the same experimental procedure [15]. These neutral complexes feature ethanol as D ligand and their ${ }^{1} \mathrm{H}$ NMR spectra display signals corresponding to the bonded and free $\mathrm{D}$ molecule $\left(\mathrm{D}=\mathrm{EtOH}, \mathrm{H}_{2} \mathrm{O}, \mathrm{DMSO}\right)$ in fast exchange [15].

By IR spectroscopy, the presence of the sulfonato groups for both ligands and complexes is confirmed by three stretching frequencies in the range $1000-1200 \mathrm{~cm}^{-1}[21]$. The Schiff-base structure for the salicylidene part of compounds 1-4 is confirmed by the strong characteristic imine band occurring in the range 1617-1659 $\mathrm{cm}^{-1}$. Coordination of the imine centre onto the molybdenum atom results in a slightly lower $v(\mathrm{C}=\mathrm{N})$ stretching frequency for the complexes 3 and 4 (1617 and $1640 \mathrm{~cm}^{-1}$ respectively) than for the free Schiff bases $\mathbf{1}$ and 2 (1621 and $1659 \mathrm{~cm}^{-1}$ respectively). In addition, two IR absorptions observed for $\mathbf{3}$ and $\mathbf{4}$, attributable to asymmetric and symmetric $\mathrm{Mo}=\mathrm{O}$ stretches of the cis- $\mathrm{MoO}_{2}{ }^{2+}$ moiety (in the range 900-930), are typical of $\mathrm{MoO}_{2} \mathrm{LD}$ structures.

Compounds 1-4 have also been identified by FAB spectrometry in the negative mode, showing the anion mass with the correct isotopic distribution. For ligands $\mathbf{1}$ and $\mathbf{2}$, aggregates are observed with the sodium cation. The FAB spectrometric analysis of the ammonium complex 5 showed the anion in the negative mode and the corresponding $\mathrm{NBu}_{4}{ }^{+}$cation in the positive mode.

\subsection{X-ray diffraction analysis for complexes $\mathbf{3}$ and $\mathbf{5}$}

The molecular structures of $\mathbf{3}$ and $\mathbf{5}$ with the atom numbering shown in Figure 1 and Figure 2 are typical examples of cis- $\mathrm{MoO}_{2}$ complexes. The anionic molybdenum complex displays the same coordination geometry in the two salts, corresponding to a distorted octahedron where the sulfonato group of the adjacent complex occupies the sixth coordination site. The tridentate Schiff base ligand binds the molybdenum atom in a mer coordination 
mode through the $\mathrm{N}(1), \mathrm{O}(1)$ and $\mathrm{O}(2)$ anionic oxygen atoms. The weaker $\pi$-donors (the nitrogen atom and the oxygen atom of the sulfonate group) are trans to one oxido ligand. The relative arrangement of the adjacent molecules is the same in the two structures, with a mutual head-tail arrangement of two anions to generate pseudo-dimers. The sodium cation in $\mathbf{3}$ (see Figure 1) also features pseudo-octahedral coordination with two cis positions occupied by the sulfonate $\mathrm{O}(5)$ atom and the $\mathrm{O}(4)$ atom from the $\mathrm{Mo}=\mathrm{O}$ function located trans to the sSAP N atom. The remaining four coordination positions are occupied by water molecules, two of which bridge the sodium atom with a symmetry equivalent (inversion center) sodium atom, generating an infinite network which includes $\mathrm{H}$-bonds (a table of $\mathrm{H}$-bonding parameters is available in the Supporting Information). In the structure of 5, on the other hand, the ammonium cations do not establish any close contact with the anionic part, which is therefore featured by discrete and isolated pseudo-dimers (Figure 2).

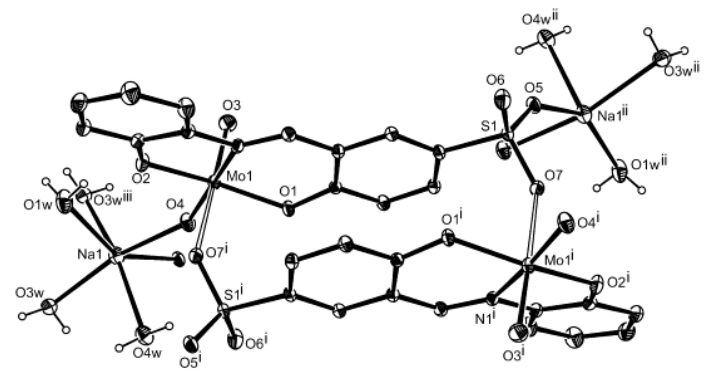

Figure 1. An ORTEP view of the molecular structure of compound 3. The ellipsoids are shown at the $30 \%$ probability level.

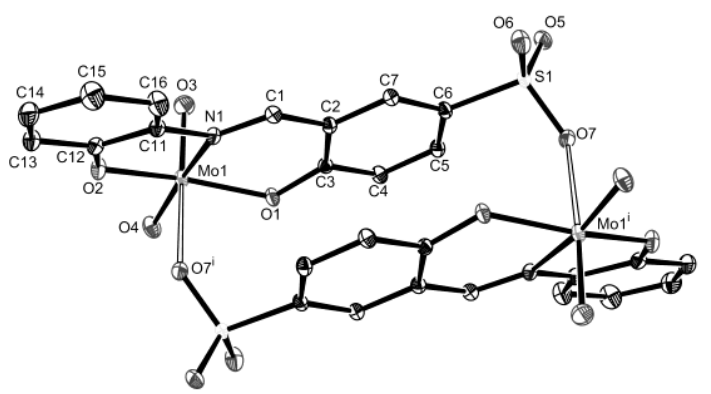


Figure 2. On ORTEP view of the molecular structure of compound 5. The ellipsoids are shown at the $30 \%$ probability level.

Selected bond distances and angles for the two structures are collected and compared in Table 2. The Mo-O(3) and Mo-O(4) bond distances (1.688(1)-1.707(5) $\AA$ ) as well as the $\mathrm{O}(3)-\mathrm{Mo}(1)-\mathrm{O}(4)$ angle $\left(105^{\circ}\right)$ represent the expected values known from literature [22]. In compound 3 , atom $\mathrm{O}(4)$ engages in the interaction with the $\mathrm{Na}$ cation, whereas $\mathrm{O}(3)$ does not establish any additional interaction. However, both $\mathrm{Mo}=\mathrm{O}$ bond display approximately the same slight shortening on going from $\mathbf{3}$ to $\mathbf{5}$, which is hardly significant. The presence of the $\mathrm{Mo}=\mathrm{O} \cdots \mathrm{Na}$ interaction is reflected more strongly on the bond angles, both the $\mathrm{O}(3)-\mathrm{Mo}(1)-$ $\mathrm{N}(1)$ and $\mathrm{O}(4)-\mathrm{Mo}(1)-\mathrm{N}(1)$ angles changing significantly on going from $\mathbf{3}$ to $\mathbf{5}$, whereas the $\mathrm{O}(3)-\mathrm{Mo}(1)-\mathrm{O}(4)$ angle remains essentially unaffected. The other bonding parameters are very similar in the two compounds. Due to the trans effect of the oxido functionalities, the Mo(1)$\mathrm{N}(1)$ and $\mathrm{Mo}(1)-\mathrm{O}(7)$ bond distances experience a lengthening. The $\mathrm{Mo}(1)-\mathrm{O}(7)$ bond lengths are similar to the corresponding molybdenum-oxygen bond (2.331 $\mathrm{A}$ ) of the N-salicylidene-2aminobenzenethiolato sulfonate dioxidomolydenum(VI) complex associated with the $\mathrm{Me}_{4} \mathrm{~N}^{+}$ cation described by Holm and co-workers [23]. These distances also correlate well with the bonding of a labile coordinated solvent molecule reported for other $\mathrm{MoO}_{2} \mathrm{~L}(\mathrm{D})$ compounds [22a].

Table 2 - Relevant crystallographic distances $(\AA)$ and angles $\left(^{\circ}\right)$ for $\mathbf{3}$ and $\mathbf{5}$

\begin{tabular}{cccccc}
\hline Bond lengths & $\mathbf{3}$ & $\mathbf{5}$ & Angles & $\mathbf{3}$ & $\mathbf{5}$ \\
\hline $\mathrm{Mo}(1)-\mathrm{O}(1)$ & $1.936(1)$ & $1.945(2)$ & $\mathrm{O}(3)-\mathrm{Mo}(1)-\mathrm{O}(4)$ & $105.44(7)$ & $105.03(8)$ \\
$\mathrm{Mo}(1)-\mathrm{O}(2)$ & $1.971(1)$ & $1.952(2)$ & $\mathrm{O}(3)-\mathrm{Mo}(1)-\mathrm{O}(1)$ & $97.34(6)$ & $95.93(8)$ \\
$\mathrm{Mo}(1)-\mathrm{O}(3)$ & $1.700(1)$ & $1.688(2)$ & $\mathrm{O}(4)-\mathrm{Mo}(1)-\mathrm{O}(1)$ & $102.01(6)$ & $101.56(8)$ \\
$\mathrm{Mo}(1)-\mathrm{O}(4)$ & $1.708(1)$ & $1.699(2)$ & $\mathrm{O}(3)-\mathrm{Mo}(1)-\mathrm{O}(2)$ & $98.92(7)$ & $98.32(9)$
\end{tabular}




$$
\begin{array}{cccccc}
\mathrm{Mo}(1)-\mathrm{O}(7)^{\mathrm{i}} & 2.367(1) & 2.270(2) & \mathrm{O}(4)-\mathrm{Mo}(1)-\mathrm{O}(2) & 95.92(6) & 97.93(8) \\
\mathrm{Mo}(1)-\mathrm{N}(1) & 2.274(2) & 2.285(2) & \mathrm{O}(1)-\mathrm{Mo}(1)-\mathrm{O}(2) & 151.58(6) & 151.92(7) \\
\mathrm{C}(1)-\mathrm{N}(1) & 1.293(2) & 1.279(3) & \mathrm{O}(3)-\mathrm{Mo}(1)-\mathrm{N}(1) & 91.72(6) & 87.40(8) \\
\mathrm{O}(7)-\mathrm{S}(1) & 1.485(1) & 1.474(2) & \mathrm{O}(4)-\mathrm{Mo}(1)-\mathrm{N}(1) & 161.82(6) & 166.62(7)
\end{array}
$$

Symmetry codes: (i) $x, y+1, z+1$

\section{4. $\mathrm{X}$-ray crystallographic analysis of $\left[\mathrm{HOCH}_{2} \mathrm{CH}_{2} \mathrm{NH}_{3}\right]\left[\mathrm{H}_{2} \mathrm{SSAE}\right]$}

Slow solvent evaporation of an ethanol solution from the synthesis of $\mathrm{NaH}_{2} \mathrm{SSAE}$ afforded suitable crystals for X-ray diffraction. The X-ray structure, however, reveals that the associated cation is not sodium but rather the ethanol-ammonium arising from protonation of the slight excess of the 2-amino-1-ethanol precursor in the ligand synthesis. A view of the structure is shown in Figure 3. The asymmetric unit consists of two independent cation-anion pairs, labelled as Molecule 1 and Molecule 2. The cations and anions are in close contact through an extended network of H-bonds. The two anions establish several identical interactions: the alcohol function of each anion interacts with the sulfonate group of the other anion in an infinite chain fashion, while atoms O14/24 interact with atoms N15/25 (intramolecular) and with atoms $\mathrm{N} 1 / 2$ of the corresponding cation. The remaining interactions of the sulfonate oxygen atoms, however, differ: whereas those of Anion 1 are established with the $\mathrm{N}$ atoms of the two different cations $(\mathrm{O} 12 \cdots \mathrm{N} 1$ and $\mathrm{O} 13 \cdots \mathrm{N} 2$ shown in Figure 4), those of Anion 2 are correspondingly established with the alcohol part of symmetry related cations $(\mathrm{O} 21 \cdots \mathrm{O} 2$ and $\mathrm{O} 23 \cdots \mathrm{O} 1$, not shown in Figure 3$)$. The alcohol functions of the cations, in addition to the above mentioned interactions as proton donors, also establish interactions as proton acceptors with ammonium functions of symmetry-related cations $(\mathrm{O} 1 \cdots \mathrm{N} 1$ and $\mathrm{O} 2 \cdots \mathrm{N} 2)$. The packing diagram and the list of $\mathrm{H}$-bonding contacts are available as Supporting Information. 


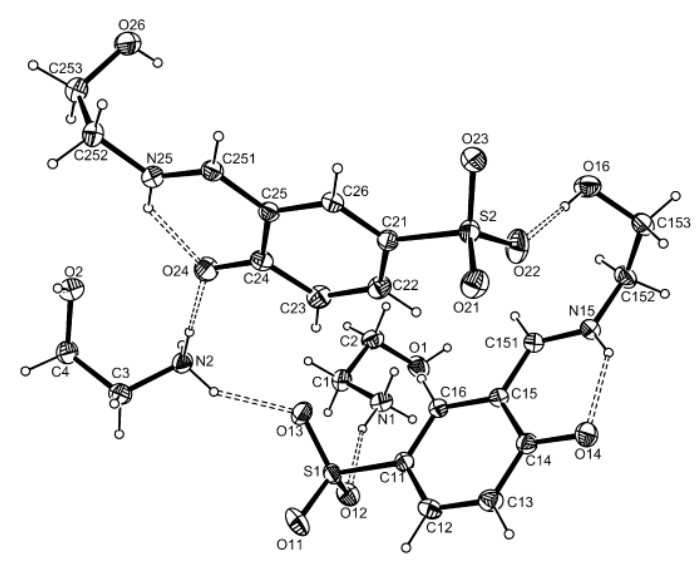

Figure 3. An ORTEP view of the asymmetric unit in the structure of $\left[\mathrm{HOCH}_{2} \mathrm{CH}_{2} \mathrm{NH}_{3}\right]\left[\mathrm{H}_{2} \mathrm{SAE}\right]$. Ellipsoids are shown at the $30 \%$ probability level. For Anion 1, only one of the two disordered tautomeric forms is shown (see Experimental).

The two anions differ in one important aspect: while for Molecule $1 \mathrm{a} \mathrm{H}$ atom was located on atom $\mathrm{N} 15$ and not on atom $\mathrm{O} 14$ (thereby giving rise to the quinoid tautomeric form of the iminophenol moiety), Molecule 2 showed two distinct electron densities of approximately equal intensity near atoms N25 and O24, suggesting the coexistence of both tautomeric forms in the solid state. In other words, Molecule 2 is disordered with equal contribution of the two tautomers. This disorder is reflected in the significantly different bond length pattern involving the $o-\mathrm{OC}_{6} \mathrm{H}_{4} \mathrm{CH}_{2} \mathrm{~N}$ moiety. Selected bond distances and angles are collected in Table 3. Molecule 2 shows a bond distance pattern closer to that expected for the quinoid form, with $\mathrm{O}(24)-\mathrm{C}(24)$ shorter than $\mathrm{O}(14)-\mathrm{C}(14)$. The $\mathrm{C}(24)-\mathrm{O}(24)$ bond length is significantly shorter than the standard single C-O bond (1.339 ̊) and falls almost in the range for standard double C-O bonds (1.279 $\AA$ ) [24]. The $\mathrm{C}(24)-\mathrm{C}(25)$ bond is longer than $\mathrm{C}(14)$ $\mathrm{C}(15), \mathrm{C}(25)-\mathrm{C}(251)$ shorter than $\mathrm{C}(15)-\mathrm{C}(151)$, and $\mathrm{N}(25)-\mathrm{C}(251)$ longer than $\mathrm{N}(15)-\mathrm{C}(151)$, consistent with the expected different localization of the $\pi$ electron density in the two 
tautomeric forms. The coexistence of different tautomeric forms within the same crystal structure for $o$-iminophenolates is precedented in the literature [25]. The sulfonato group of the salicylidene moiety could increase, through electronic effects transmitted by the aromatic ring, the acidity of the $\mathrm{OH}$ proton promoting proton transfer from the oxygen to the nitrogen site [26].

Table 3. Relevant crystallographic distances $(\AA)$ and angles $\left(^{\circ}\right)$ for compound $\left[\mathrm{HOCH}_{2} \mathrm{CH}_{2} \mathrm{NH}_{3}\right]\left[\mathrm{H}_{2} \mathrm{SSAE}\right]$.

\begin{tabular}{llll}
\hline \multicolumn{3}{c}{ Molecule 1} & Molecule 2 \\
\hline \multicolumn{5}{c}{ Bond lengths } \\
\hline $\mathrm{O}(14)-\mathrm{C}(14)$ & $1.317(1)$ & $\mathrm{O}(24)-\mathrm{C}(24)$ & $1.286(1)$ \\
$\mathrm{N}(15)-\mathrm{C}(151)$ & $1.283(2)$ & $\mathrm{N}(25)-\mathrm{C}(251)$ & $1.295(2)$ \\
$\mathrm{C}(15)-\mathrm{C}(151)$ & $1.435(3)$ & $\mathrm{C}(25)-\mathrm{C}(251)$ & $1.422(3)$ \\
$\mathrm{C}(11)-\mathrm{C}(12)$ & $1.401(2)$ & $\mathrm{C}(21)-\mathrm{C}(22)$ & $1.409(2)$ \\
$\mathrm{C}(12)-\mathrm{C}(13)$ & $1.381(2)$ & $\mathrm{C}(22)-\mathrm{C}(23)$ & $1.374(2)$ \\
$\mathrm{C}(13)-\mathrm{C}(14)$ & $1.410(2)$ & $\mathrm{C}(23)-\mathrm{C}(24)$ & $1.429(2)$ \\
$\mathrm{C}(14)-\mathrm{C}(15)$ & $1.423(2)$ & $\mathrm{C}(24)-\mathrm{C}(25)$ & $1.436(2)$ \\
$\mathrm{C}(15)-\mathrm{C}(16)$ & $1.402(2)$ & $\mathrm{C}(25)-\mathrm{C}(26)$ & $1.409(2)$ \\
$\mathrm{C}(11)-\mathrm{C}(16)$ & $1.382(2)$ & $\mathrm{C}(21)-\mathrm{C}(26)$ & $1.376(2)$
\end{tabular}

Bond angles

\begin{tabular}{llll}
\hline $\mathrm{O}(14)-\mathrm{C}(14)-\mathrm{C}(15)$ & $121.1(1)$ & $\mathrm{O}(24)-\mathrm{C}(24)-\mathrm{C}(25)$ & $120.9(1)$ \\
$\mathrm{C}(14)-\mathrm{C}(15)-\mathrm{C}(151)$ & $120.9(1)$ & $\mathrm{C}(24)-\mathrm{C}(25)-\mathrm{C}(251)$ & $120.8(1)$ \\
$\mathrm{N}(15)-\mathrm{C}(151)-\mathrm{C}(15)$ & $122.0(1)$ & $\mathrm{N}(25)-\mathrm{C}(251)-\mathrm{C}(25)$ & $123.2(1)$ \\
\hline
\end{tabular}


Tridentate neutral "ONO" Schiff base ligands form $\mathrm{MoO}_{2}(\mathrm{~L})(\mathrm{D})(\mathrm{D}=$ solvent $)$ complexes in equilibrium with the $\mu$-oxido dimeric $[\mathrm{MoO}(\mu-\mathrm{O})(\mathrm{L})]_{2}$ in solution [15], [27]. These dioxidomolybdenum(VI) complexes show good catalytic activities for the epoxidation of cyclohexene [12a] and unsaturated fatty acids [12b] with tert-butyl-hydroperoxide (TBHP) as oxidant. In fact, this system features a cis-dioxidometal unit and an open coordination site for the oxidant activation useful for catalytic oxidation reactions. Chiral versions bearing sugar derived Schiff base ligands exhibit the same catalytic performance for cyclooctene epoxidation but moderate enantiomeric induction for cis- $\beta$-methyl styrene [12c]. Additionally, Kühn and co-workers have studied the catalytic performance of the aminocyclohexanol derived chiral Schiff base molybdenum(VI) cis-dioxido complex that gave moderate activity for cyclooctene epoxidation probably due to its poor solubility [12d].

To the best of our knowledge, only two dioxidomolydenum(VI) complexes, the $\mathrm{N}$ salicylidene-2-aminobenzenethiolato sulfonate dioxidomolydenum(VI) complexes bearing a sulfonated tridentate "ONS" ligand, have been prepared to date as ammonium salts (i.e. with $\mathrm{Me}_{4} \mathrm{~N}^{+}$and $n-\mathrm{Pr}_{4} \mathrm{~N}^{+}$cations) [23]. Unfortunately, these particular complexes were not tested for catalysis and only little is known about their catalytic applicability.

Conversely, tetradentate salen ligands that possess incorporated anionic sulfonato functionalities on the salicylidene backbone have yielded valuable catalysts for oxidation reactions in polar solvents [28]. This observation suggest that our synthesized sulfonated tridentate complexes might also hold potential for catalysis in both water and in ILs, motivating us to screen them in epoxidation reactions using cyclooctene as model substrate.

A first trial was carried out using $t$-butyl hydroperoxide (TBHP, $70 \%$ in water) as oxidant with $\mathbf{3}$ as catalyst (see Table 4, run 1). The catalyst was entirely soluble in the aqueous phase under our experimental conditions. However, only a modest epoxide yield (i.e. around 52\%) was achieved after 8 hours. An independent ${ }^{1} \mathrm{H}$ NMR study in $\mathrm{D}_{2} \mathrm{O}$ revealed 
that catalyst $\mathbf{3}$ is decomposed by TBHP. The formation of the salicylaldehyde-5-sulfonate was observed arising from hydrolysis of the Schiff base imine. This product was also seen on the ${ }^{1} \mathrm{H}$ NMR spectrum of the aqueous phase in $\mathrm{D}_{2} \mathrm{O}$ taken after the catalytic run.

Considering the tendency of Schiff base ligands and in some cases of the corresponding metal complexes to hydrolyse in water-containing solvent (under certain $\mathrm{pH}$ conditions) [29], we then decided to work with decane solutions of TBHP and to perform the catalysis at lower temperature (run 2). Without any additional solvent (other than decane), also low activity towards cyclooctene oxide formation was obtained in the catalytic trial (i.e. around $46 \%$ in epoxide yield after $7.5 \mathrm{~h}$ ).

Table 4: Epoxidation of cyclooctene catalyzed by $\mathbf{3}$ in different media

\begin{tabular}{llccc}
\hline Run & Solvent & $\begin{array}{c}\text { Temperature } \\
\left({ }^{\circ} \mathrm{C}\right)\end{array}$ & $\begin{array}{c}\text { Reaction } \\
\text { time }(\text { min })\end{array}$ & $\begin{array}{c}\text { Epoxide } \\
\text { yield }(\%)\end{array}$ \\
\hline 1 & Water $^{(\mathrm{a})}$ & $80^{\circ} \mathrm{C}$ & 260 & 43 \\
& & & 480 & 52 \\
2 & No solvent $^{(\mathrm{a})}$ & $55^{\circ} \mathrm{C}$ & 279 & 30 \\
3 & {$[\mathrm{BMIM}]\left[\mathrm{NTf}_{2}\right]^{(\mathrm{b})}$} & $55^{\circ} \mathrm{C}$ & 271 & 46 \\
4 & {$[\mathrm{BMIM}]\left[\mathrm{CF}_{3} \mathrm{SO}_{3}\right]^{(\mathrm{b})}$} & $55^{\circ} \mathrm{C}$ & 261 & 62 \\
5 & {$[\mathrm{EMIM}]\left[\mathrm{CH}_{3} \mathrm{C}_{6} \mathrm{H}_{4} \mathrm{SO}_{3}\right]^{(\mathrm{b})}$} & $55^{\circ} \mathrm{C}$ & 226 & 5 \\
6 & {$[\mathrm{BMIM}]\left[\mathrm{NTf}_{2}\right] /$} & $55^{\circ} \mathrm{C}$ & 297 & 35 \\
\hline
\end{tabular}

(a) TBHP $70 \%$ in water was used with a catalyst: substrate: oxidant ratio of 0.75: 100: 400

(b) TBHP 5.5 M in decane was used with a catalyst: substrate: oxidant ratio of 1: 100: 200

Next, we decided to switch to biphasic conditions in ILs, still using compound $\mathbf{3}$ as catalyst and focused on $[\mathrm{BMIM}]\left[\mathrm{NTf}_{2}\right],[\mathrm{BMIM}]\left[\mathrm{CF}_{3} \mathrm{SO}_{3}\right]$ and $[\mathrm{EMIM}]\left[\mathrm{CH}_{3} \mathrm{C}_{6} \mathrm{H}_{4} \mathrm{SO}_{3}\right]$. The two latter sulfonate ILs were chosen for their structural similarity with the sulfonated catalyst, whereas $[\mathrm{BMIM}]\left[\mathrm{NTf}_{2}\right]$ was selected because of the high activity already reported for the cyclooctene epoxidation catalyzed by dioxidomolybdenum(VI) complexes [13]. The cyclooctene epoxidation was carried out under the same experimental conditions used in the catalytic trial without the solvent but with the addition of $0.5 \mathrm{~mL}$ of IL. The results are 
presented in Figure 4. The catalyst did not exhibit the expected solubility in the two ILs featuring sulfonate anions. The lowest activity was observed with the ILs [BMIM] $\left[\mathrm{CF}_{3} \mathrm{SO}_{3}\right]$ and [EMIM] $\left[\mathrm{CH}_{3} \mathrm{C}_{6} \mathrm{H}_{4} \mathrm{SO}_{3}\right]$ (see runs 4 and 5 in Table 4), likely due to low solubility of the catalyst and high viscosity of the reaction medium, especially in the case of [EMIM] $\left[\mathrm{CH}_{3} \mathrm{C}_{6} \mathrm{H}_{4} \mathrm{SO}_{3}\right]$. In fact, the obtained data showed even lower activity for the epoxidation in comparison to the control run (run 2 in Table 4) in the absence of any IL in the reaction media. The use of the more conventional $[\mathrm{BMIM}]\left[\mathrm{PF}_{6}\right]$ led to an initial small yield of epoxide, followed by its complete disappearance, probably because of diol formation as previously described for other catalysts [13b].

Nevertheless, also an improved influence of the investigated IL systems was observed. The highest activity was found using the IL [BMIM][NTf $]$ (run 3, Table 4), although the catalyst solubility is still modest. Thus, like for other literature reports, we find that the catalytic activity can be significantly affected by the nature of the ionic liquid [30]. The best result obtained with the IL $[\mathrm{BMIM}]\left[\mathrm{NTf}_{2}\right]$ correlates well with the same activity enhancement observed by Valente et al [13a] and Kühn et al [13b] in the case of their Mo(VI) catalysts in combination with this IL. An additional test was carried out as well in a 1:4 mixture of the ILs [EMIM] $\left[\mathrm{CH}_{3} \mathrm{C}_{6} \mathrm{H}_{4} \mathrm{SO}_{3}\right]$ and $[\mathrm{BMIM}]\left[\mathrm{NTf}_{2}\right]$ (run 6, Table 4), with the goal to take advantage of the combined increased solubility and activity effects. Although a great increase in solubility was not achieved, the catalytic reactivity was found to be intermediate in comparison to those obtained using each IL by itself, directly reflecting the positive effect of the IL [BMIM] $\left[\mathrm{NTf}_{2}\right]$. 


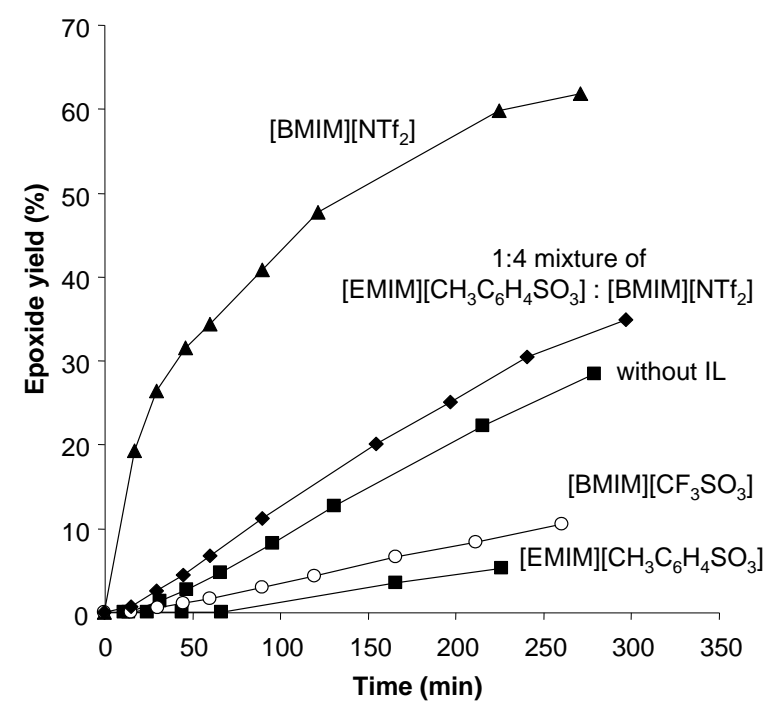

Figure 4. Comparison of the catalytic activity of $\mathbf{3}$ in different IL media.

Finally, we focused on a comparison of catalytic performances for catalysts $3, \mathbf{4}$ and $\mathbf{5}$ in $[\mathrm{BMIM}]\left[\mathrm{NTf}_{2}\right]$. The kinetic profiles are shown in Figure 5. Differences in the kinetic profile between the two catalysts $\mathbf{3}$ and $\mathbf{5}$ being only slight, the nature of the associated cation does not seem to play a crucial role in the catalysis. Conversely, it appears that the catalyst 4 containing the sSAE presents a lower activity than the complexes containing the sSAP ligand.

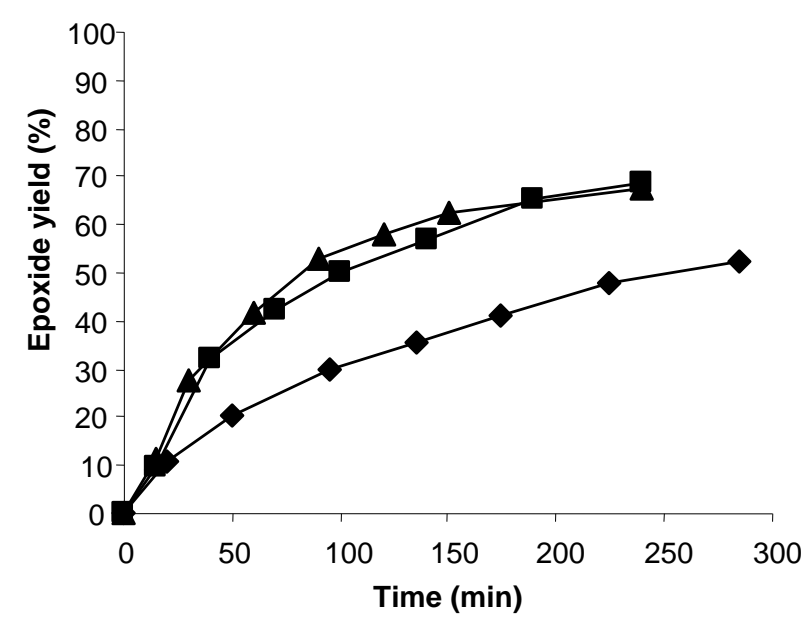

Figure 5. Comparison of the catalysts $\mathbf{3}$ (triangles), 4 (diamonds) and $\mathbf{5}$ (squares) in cyclooctene epoxidation in [BMIM] $\left[\mathrm{NTf}_{2}\right]$. 
As shown in the kinetic profile of Figure 6 for catalyst 3 in [BMIM] $\left[\mathrm{NTf}_{2}\right]$, the sum of cyclooctene oxide and cyclooctene does not add up to a value of $100 \%$, a feature observed for all the biphasic systems described in this report. Additionally, no side products that may account for the difference to $100 \%$ were observed by GC/MS analysis.

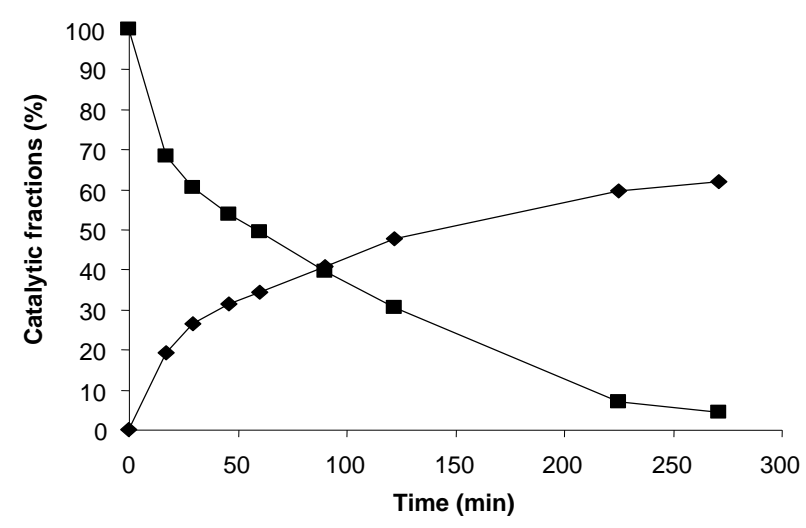

Figure 6: Kinetic profile for cyclooctene epoxidation with catalyst 3 in [BMIM][NTf ${ }_{2}$. Squares: cyclooctene residual fraction; diamonds: cyclooctene oxide yield.

One explanation could be that the cyclooctene oxide is partially miscible in the IL $[\mathrm{BMIM}]\left[\mathrm{NTf}_{2}\right]$ at the reaction temperature. To underline this hypothesis, extraction of the IL phase after the catalytic run (at $270 \mathrm{~min}$ ) with pentane was envisaged followed by injection of the organic phase into the GC. The measured catalytic fractions (residual cyclooctene and epoxide yield) went respectively from 16 and $66 \%$ in the absence of extraction to 14 and $86 \%$ by the new procedure. This result shows that, for the cyclooctene oxide, a mass transfer occurs between the two phases during the catalysis because the epoxide is partitioning between the two phases.

Thus far, we presented the synthesis of new ionophilic dioxidomolybdenum complexes and their application in cyclooctene epoxidation in ILs. However, one of the main advantages of using ILs as reaction media is the possibility of reusing the IL phase along with the dissolved or immobilized metal catalyst. Therefore, we studied the recyclability of the most promising catalytic system in our hands, the catalyst 3 in the ionic liquid [BMIM] $\left[\mathrm{NTf}_{2}\right]$ (see Table 5). 
Utilization of recycled catalyst showed similar activity in the second cycle. To our surprise we found for compound $\mathbf{3}$ in the second run even a slightly bigger activity relative to the first cycle. This is likely due to difficulties in the experimental procedure, related to the low solubility of catalyst $\mathbf{3}$ in the reaction media. Previously, we obtained a $86 \%$ yield of epoxide for this reaction (see above). After three consecutive reactions, the catalytic activity decreased significantly to yield only $38 \%$ of cyclooctene oxide, probably due to incremental metal loss during the extraction processes. The fifth and final cycle yielded only $19 \%$ of cyclooctene oxide. The recycling performance of $\mathbf{3}$ is comparable to other previously published $\mathrm{Mo}^{\mathrm{VI}}$ catalysts $[13 \mathrm{a}, 13 \mathrm{~b}]$

Table 5: Recycling of catalyst 3 in [BMIM] $\left[\mathrm{NTf}_{2}\right]$

\begin{tabular}{|c|c|c|}
\hline Cycles & Epoxide yield $(\%)^{(\mathrm{a})}$ & $\begin{array}{l}\text { Residual cyclooctene } \\
\text { fraction }(\%)^{(a)}\end{array}$ \\
\hline 1 & 70 & 22 \\
\hline 2 & 79 & 14 \\
\hline 3 & 66 & 27 \\
\hline 4 & 38 & 55 \\
\hline 5 & 19 & 74 \\
\hline
\end{tabular}

(a) Yield by GC obtained after 270 min of reaction at $55^{\circ} \mathrm{C}$.

\section{Conclusion}

Diprotic anionic sulfonated Schiff bases (of "ONO"-type) have been assembled by straightforward synthetic procedures that allow the facile introduction of different motifs on the imine function. The corresponding sulfonated Schiff base dioxidomolybdenum complexes have been easily prepared by reaction with the $\mathrm{MoO}_{2}(\mathrm{acac})_{2}$ precursor. They have been engaged in the cyclooctene epoxidation in IL media with TBHP as oxidant. The best catalytic systems are the salts of $\mathrm{N}$-salicylidene-2-aminophenolate sulfonate dioxidomolybdenum(VI), 
$\mathbf{3}$ and $\mathbf{5}$, in the ionic liquid $[\mathrm{BMIM}]\left[\mathrm{NTf}_{2}\right]$. We showed that in the case of catalyst $\mathbf{3}$ in $[\mathrm{BMIM}]\left[\mathrm{NTf}_{2}\right]$, the IL phase along with the immobilized catalyst can be reused for at least three runs with a fairly comparable catalytic activity.

\section{Appendix A. Supplementary data}

Crystallographic data (excluding structure factors) have been deposited with the Cambridge Crystallographic Data Centre as supplementary publication no. CCDC 727532 for $\left[\mathrm{HOCH}_{2} \mathrm{CH}_{2} \mathrm{NH}_{3}\right]\left[\mathrm{H}_{2} \mathrm{SSAE}\right], 727533$ for $\mathbf{3}$ and 727534 for $\mathbf{5}$. Copies of the data can be obtained free of charge via http://www.ccdc.cam.ac.uk/conts/retrieving.html, or from the Cambridge Crystallographic Data Centre, 12 Union Road, Cambridge CB2 1EZ, UK; fax: (+44) 1223-336-033; or e-mail: deposit@ccdc.cam.ac.uk. Other supplementary data associated with this article $\left({ }^{1} \mathrm{H}\right.$ and ${ }^{13} \mathrm{C}\left\{{ }^{1} \mathrm{H}\right\}$ NMR spectra of all compounds; views of crystal packing and tables of $\mathrm{H}$-bond distances for 3 and $\left[\mathrm{HOCH}_{2} \mathrm{CH}_{2} \mathrm{NH}_{3}\right]\left[\mathrm{H}_{2} \mathrm{sSAE}\right]$ ) can be found in the online version.

\section{References}

[1] (a) B. Cornils, Angew. Chem. Int. Ed. Engl. (1995) 1575;

(b) W. A. Herrmann, C. W. Kohlpaintner, Angew. Chem. Int. Ed. Engl. 32 (1993) 1524;

(c) K. H. Shaughnessy, Chem. Rev. 109 (2009) 643.

[2] (a) Y. Chauvin, S. Einloft, H. Olivier, Ind. Eng. Chem. Res. 34 (1995) 1149;

(b) Y. Chauvin, B. Gilbert, I. Guibard, J. Chem. Soc., Chem. Commun. (1990) 1715.

[3] (a) T. Welton, Chem. Rev. 99 (1999) 2071;

(b) M. J. Earle, K. R. Seddon, Pure Appl. Chem. 72 (2000) 1391.

[4] (a) P. Wasserscheid, W. Keim, Angew. Chem. Int. Ed. 39 (2000) 3772; 
(b) R. Sheldon, Chem. Commun. (2001), 2399;

(c) J. Dupont, R. F. de Souza, P. A. Z. Suarez, Chem. Rev. 102 (2002) 3667;

(d) V. I. Pârvulescu, C. Hardacre, Chem. Rev. 107 (2007) 2615.

[5] J. Muzard, Adv. Synth. Catal. 348 (2006) 275.

[6] J. Dupont, J. Spencer, Angew. Chem. Int. Ed. 43 (2004), 5296.

[7] (a) E. D. Jacobsen, A. Pfaltz, H. Yamamoto (Eds), Comprehensive Asymmetric Catalysis, Vol 2, Springer-Verlag: Berlin, Germany, 1999;

(b) T. Katsuki, Coord. Chem. Rev. 140 (1995) 189;

(c) T. P. Yoon, E. N. Jacobsen, Science 299 (2003), 1691;

(d) J. F. Larrow, E. N. Jacobsen, Top. Organomet. Chem. 6 (2004) 123;

(e) L. Canali, D. C. Sherrington, Chem. Soc. Rev. 28 (1999) 85.

[8] (a) C. E. Song, E. J. Roh, Chem. Commun. (2000) 837;

(b) K. Smith, S. Liu, G. A. El-Hiti, Catal. Lett. (2004) 95;

(c) L. D. Pinto, J. Dupont, R. F. de Souza, K. Bernado-Gusmao, Catal. Commmun. 9 (2008) 135.

[9] (a) F. E. Kühn, J. Zhao, W. A. Herrmann, Tetrahedron: Asymmetry 16 (2005), 3469;

(b) K. R. Jain, W. A. Herrmann, F. E. Kühn, Coord. Chem. Rev. 252 (2008) 556.

[10] (a) F. E. Kühn, A. M. Santos, A. D. Lopes, I. S. Gonçalves, J. E. Rodríguez-Borges, M. Pillinger, C. C. Romão, J. Organomet. Chem. 621 (2001) 207;

(b) F. E. Kühn, A. D. Lopes, A. M. Santos, E. Herdtweck, J. J. Haider, C. C. Romão, A. G. Santos, J. Mol. Catal. A: Chem. 151 (2000) 147;

(c) A. A. Valente, I. S. Rodríguez-Borges, M. Pillinger, C. C. Romão, J. Rocha, X. GarcíaMera, New J. Chem. 25 (2001) 959;

(d) J. Fridgen, W. A. Herrmann, G. Eickerling, A. M. Santos, F. E. Kühn, J. Organomet. Chem. 689 (2004) 2752; 
(e) A. Al-Ajlouni, A. A. Valente, C. D. Numes, M. Pillinger, A. M. Santos, J. Zhao, C. C. Romão, I. S. Rodríguez-Borges, F. E. Kühn, Eur. J. Inorg. Chem. (2005) 1716.

[11] (a) Y. -L. Wong, Y. Yan, E. S. H. Chan, Q. Yang, T. C. W. Mak, D. K. P. Ng, J. Chem. Soc., Dalton Trans. (1998) 3057;

(b) X. -Y. Wang, H. -C. Shi, C. Suan, C. Sun, Z. -G. Zhang, Tetrahedron 60 (2004) 10993;

(c) S. M. Bruno, S. S. Baluta, A. A. Valente, F. A. Almeida Paz, M. Pillinger, C. Sousa, J. Klinowski, C. Freire, P. Ribeiro-Claro, I. S. Gonçalves, J. Mol. Catal. A: Chem. 270 (2007) 185.

[12] (a) Y. Sui, X. Zeng, X. Fang, X. Fu, Y. Xiao, L. Chen, M. Li, S. Cheng, J. Mol. Catal. A: Chem. 270 (2007) 61;

(b) J. M. Sobczak, J. J. Ziółkowski, Appl. Catal. A. 248 (2003) 261;

(c) J. Zhao, X. Zhou, A. M. Santos, E. Herdtweck, C. C. Romão, F. E. Kühn, Dalton Trans. (2003) 3736;

(d) X. Zhou, J. Zhao, A. M. Santos, F. E. Kühn, Z. Naturforsch (2004) 1223.

[13] (a) A. A. Valente, Ž. Petrovski, L. C. Branco, C. A. M. Afonso, , M. Pillinger, A. D. Lopes, C. C. Romão, C. D. Nunes, I. S. Gonçalves, J. Mol. Catal. A: Chem. 218 (2004) 5;

(b) F. E. Kühn, J. Zhao, M. Abrantes, W. Sun, C. A. M. Afonso, L. C. Branco, I. S. Gonçalves, M. Pillinger, C. C. Romão, Tetrahedron Lett. 46 (2005) 47;

(c) M. Herbert, A. Galindo, F. Montilla, Catal. Commun. 8 (2007) 987.

[14] (a) F. E. Kühn, M. Goarke, E. Bencze, E. Herdweck, A. Prazeres, A. M. Santos, M. J. Calhorda, C. C. Romao, I. S. Gonçalves, A. D. Lopes, M. Pillinger, Chem. Eur. J. 8 (2002) 2370;

(b) R. A. Sheldon, J. K. Kochi, Adv. Catal. 25 (1976) 272.

[15] O. A. Rajan, A. Chakravorty, Inorg. Chem. 20 (1981) 660.

[16] G. W. Kirker, Organic Preparations and Procedures International Vol. 12 (1980) 246. 
[17] Altomare A., Burla M.C., Camalli M., Cascarano G.L., Giacovazzo C. , Guagliardi A., Moliterni A.G.G., Polidori G. \& Spagna R. SIR97- a program for automatic solution of crystal structures by direct methods. J. Appl. Cryst. 32 (1999) 115.

[18] Sheldrick, G.M. SHELXL97. Program for crystal structure refinement. University of Göttingen, Germany, 1997.

[19] Farrugia, L. J. ORTEP-3 for Windows, J. Appl. Cryst. 30 (1997) 565.

[20] (a) K. H. Walter, Chem. Ber. 95 (1962) 777;

(b) D. F. Evans, D. A. Jakubovic, Polyhedron 7 (1988) 1881;

(c) D. F. Evans, D. A. Jakubovic, Polyhedron 7 (1988) 2723;

(d) S. Dutta, A. Chakravorty, Polyhedron 13 (1994) 1811.

[21] (a) D. Chen, A. E. Martell, Y. Sun, Inorg. Chem. 28 (1989) 2647;

(b) D. M. Boghaei, M. Gharagozlou, J. Coord. Chem. 60 (2007) 339.

[22] (a) C. P. Rao, A. Sreedhara, P. V. Rao, M. B. Verghese, K. Rissanen, E. Kolehmainen, N. K. Lokanath, M. A. Sridhar, J. S. Prasad, J. Chem. Soc., Dalton Trans. (1998), 2383;

(b) H. R. Holm, Chem. Rev. 87 (1987), 1401.

[23] J. A. Craig, E. W. Harlan, B. S. Snyder, M. A. Whitener, R. H. Holm, Inorg. Chem. (1989) 2808.

[24] F. H. Allen, O. Kennard, D. G. Watson, L. Brammer, A. G. Orpen, R. Taylor, J. Chem. Soc., Perkin Trans. 2 (1987) S1-19.

[25] (a) H. Karabiyik, B. Güzel, M. Aygün, G. Boğa, O. Büyükgüngör, Acta Cryst. (2007) C63, o215-o218 and references herein;

(b) K. Ogawa, J. Harada, J. Mol. Struct. 647 (2003) 211.

[26] W. Schilf, B. Kamieński, A. Szady-Chełmieniecka, E. Grech, J. Mol. Struct. 700 (2004), 105.

[27] (a) J. Topich, Inorg. Chem. 20 (1981) 3704;

(b) J. M. Sobczak, T. Głowiak, J. J. Ziółkowski, Trans. Met. Chem. 15 (1990) 208; 
(c) D. Agustin, C. Bibal, B. Neveux, J. C. Daran, R. Poli, accepted for publication in Z. Anorg. Allg. Chem.

[28] (a) S. Battacharjee, J. A. Anderson, Chem. Commun. (2004), 554;

(b) S. Battacharjee, T. J. Dines, J. A. Anderson, J. Catal. 225 (2004) 398;

(c) S. Battacharjee, J. A. Anderson, Adv. Synth. Catal. 348 (2006) 151;

(d) B. M. Choudary, T. Raman, H. Makeswaran, L. Prashant, K. V. S. Ranganath, K. V. Kumar, Adv. Synth. Catal. 348 (2006) 493;

(e) M. Lakshimi Kantam, T. Ramani, L. Chakrapani, B. M. Choudary, J. Mol. Catal. A: Chem. 274 (2007) 11;

(f) X. Tang, Y. Tang, G. Xu, S. Wei, Y. Sun, Catal. Commun. 10 (2008) 317;

(g) S. Battacharjee, J. A. Anderson, J. Mol. Catal. A: Chem 249 (2006) 103;

(h) S. Battacharjee, T. J. Dines, J. A. Anderson, J. Phys. Chem. C 112 (2008) 14124.

[29] (a) I. Correia, J. C. Pessoa, M. T. Duarte, M. F. Minas das Piedade, T. Jackush, T. Kiss, M. Margarita C. A. Castro, Carlos F. G. C. Geraldes, F. Avecilla, Eur. J. Inorg. Chem. (2005) 732 ;

(b) I. Correia, A. Dornyei, T. Jakusch, F. Avecilla, T. Kiss, J. C. Pessoa, Eur. J. Inorg. Chem. (2006) 2819.

[30] S. Liu, J. Xiao, J. Mol. Catal. A: Chem. 270 (2007) 1. 